233

Received: September 15, 2017

Accepted: December 7, 2017

\title{
EVALUATION OF NEW SLOW-GROWING CHICKEN'S GENOTYPES. II. QUALITATIVE MEAT TRAITS
}

\author{
Magdalena Oblakova ${ }^{1}$, Nadya Mincheva ${ }^{1}$, Pavlina Hristakieva ${ }^{1}$, Stefan Ribarski ${ }^{2}$, \\ Ivan Penchev ${ }^{2}$, Ivelina Ivanova ${ }^{1}$, Mitko Lalev ${ }^{1}$ \\ ${ }^{1}$ Agricultural Institute - Stara Zagora, Bulgatia \\ ${ }^{2}$ Trakia University - Stara Zagora, Bulgaria \\ moblakova@abv.bg
}

\begin{abstract}
Five groups of chickens were formed $(\mathrm{I} \times \mathrm{E}, \mathrm{M} \times \mathrm{E}, \mathrm{I} \times \mathrm{F}, \mathrm{M} \times \mathrm{F}, \mathrm{I} \times \mathrm{Ss})$, each comprising 150 unsexed day-old marked and vaccinated chicks. Chickens were reared under uniform conditions indoor, in groups, on deep permanent wooden shavings litter (indoor - floor system) following the technology used in the selection base of the Agricultural Institute - Stara Zagora. Strains used in breeding schedules used as maternal forms combined purpose Line E (Barred Plymouth Rock), Line Ss (Light Sussex), Line F, and paternal forms - the meat-type Line M (Cornish) and Line I. The analysis of meat quality traits was conducted with was performed with 3 female and 3 male chickens per group with live weight corresponding to the group average of each genotype and sex. The results from the experiment demonstrated differences in chemical and physicochemical parameters of breast muscles (except for WHC) and thigh muscle in the five studied slow-growing chicken genotypes. The meat of the $\mathrm{I} \times \mathrm{F}$ combination was outlined with high nutritional value (the highest meat protein and mineral contents; the lowest water and fat content) and with considerably lower cooking losses vs. the other studied combinations. The sex had a relevant influence on meat proximate analysis results as could be seed from the higher fat content and lower protein content of both muscles in females $(\mathrm{p}<0.001)$. The moisture and mineral contents in the thigh were not affected. Breast meat of male birds had better technological properties - high WHC as well as low cooking loss percentage for both studied muscle types. The differences in meat quality were associated with the effects of genotype, sex and their interaction.
\end{abstract}

Key words: broiler; slow-growing; slaughter analysis; productivity; chemical composition; meat quality

\section{ЕВАЛУАЦИЈА НА НОВИТЕ ГЕНОТИПОВИ БАВНОРАСТЕЧКИ ПИЛИҢА II. КВАЛИТАТИВНИ ОСОБИНИ НА МЕСОТО}

\begin{abstract}
Формирани се пет групи кокошки $(\mathrm{I} \times \mathrm{E}, \mathrm{M} \times \mathrm{E}, \mathrm{I} \times \mathrm{F}, \mathrm{M} \times \mathrm{F}, \mathrm{I} \times \mathrm{Ss})$, од кои секоја содржи 150 еднодневни означени и вакцинирани пилиња. Пилињата се одгледувани во униформни услови, затворени, во групи, на длабока постилка од дрвени струготини (систем на внатрешен под), следејќ ја технологијата што се користи во селекционата база на Земјоделскиот институт во Стара Загора. Во опитот се користени линијата E (Barred Plymouth Rock), линијата Ss (лесен сасекс), и линијата F како мајчински форми и како татковски форми месната линија М (корнски) и линија I. Анализата на особините за квалитет на месото беше спроведена на 3 женски и 3 машки пилиња по група со телесна маса што соодветствува на просекот на групите на секој генотип и пол. Резултатите од експериментот покажаа разлики во хемиските и физико-хемиските параметри на градните мускули (освен за WHC) и мускулите на бутот во петте истражувани бавнорастечки генотипови. Месото од комбинацијата $\mathrm{I} \times \mathrm{F}$ главно е со висока хранлива вредност (најголема содржина на протеини и минерали, најниска содржина на вода и масти) и со значително пониски загуби при готвењето наспроти другите проучувани комбинации. Полот има релевантно влијание врз резултатите од анализата на месото, што може да се забележи од повисоката содржина на масти и пониска содржина на протеини во испитуваните мускули кај женските единки ( $<0.001)$. Влагата и содржината на минерали во бутот не беа променети. Месото од градите кај машките единки имаше подобри технолошки својства - висок WHC, како и низок процент на загуби при готвењето кај двата изучувани типа мускули. Разликите во квалитетот на месото беа поврзани со ефектите на генотипот, полот и нивната интеракција.
\end{abstract}

Клучни зборови: бројлери; бавнорастечки; анализа на колење; продуктивност; хемиски состав; квалитет на месо 


\section{INTRODUCTION}

During the last years, the quality of foods, and poultry meat in particular, often focuses the public interest. The aim to produce high-quality, healthy and safe foods has led to orientation of consumers to meat obtained from more slowly growing birds. From the point of view of nutritional quality, the meat of slow-growing chickens is outlined with higher protein content and lower fat content compared to the meat of conventional broilers (Zanetti et al. [49], Michalczuk et al. [27], which largely satisfies the consumers' standards.

In extensive production systems, meat is produced mainly by hybrids obtained by crossing local chickens breeds with highly productive lines (Połtowicz and Doktor, 2012; Sarica et al., 2014; Sokołowicz et al., 2016). This offers the possibility for fully profiting from original chickens breeds in order to create new slowly growing combination, appropriate for rearing in organic farms or backyards. Slaughter yield, chemical composition and quality of meat are the primary criteria in the selection of genotypes. Also, apart the higher meat quality, the use of slow-growing birds has positive effects on poultry welfare (Castellini et al., 2008).

According to Petracci and Baeza (2011) poultry meat quality is a complex concept comparising chemical (protein, fat and water) and physicochemical parameters $(\mathrm{pH}$, water holding capacity, colour etc.).

Some of the most important factors influencing meat quality are genetic, e.g. selection of appropriate breed, line or hybrid (Riedel et al., 2013; Umaya, 2014; Batkowska et al., 2014), gender (López et al., 2011), slaughter age (Díaz et al., 2012; Połtowicz and Doktor, 2012; Tougan et al., 2013).

The effect of genotype on meat proximate analysis is controversial. Fanatico et al. (2005), Castellini et al. (2006), Souza et al. (2011) affirmed that dry matter, fat and ash content of the pectoralis muscle was not influenced by the genotype, although other data evidence substantial differences in the nutritional value of poultry meat. For instance, Tougan et al. (2013) reported a significant genetic effect on meat dry matter, protein and fat contents while the mineral content in the meat of five studied chicken genotypes varied within $0.97-0.99 \%$. The data reported by Lonergan et al. (2003) also showed large genotype-related variations in the chemical composition of breast muscles.

Gender-associated differences on meat nutritional value were also established (Bogosavljević-
Bošković et al., 2010; Souza et al., 2011; Eleroğlu et al., 2013).

The review of literature with respect to the effects of genotype and gender on physicochemical properties of meat also showed inconsistent results. Some researchers reported insignificant differences in physicochemical traits and WHC of meat depending on the genotype and gender (Mikulski et al., 2011; Souza et al. 2011; Fengli et al., 2013; Eleroğlu et al. 2013). while other (Debut et al., 2003; Mehaffey et al., 2006; Jaturasitha et al. (2008) affirmed that meat $\mathrm{pH}$, cooking loss and $\mathrm{WHC}$ were considerably affected by the genotype.

So far, no research data are available on the productivity of slow-growing chickens in Bulgaria, particularly with respect to their meat quality.

The study on chemical and physicochemical properties of poultry meat, continue the investigations on meat productivity of various genotypes of slow-growing chickens allows obtaining information about the nutritional value and technological properties of meat. Therefore, our purpose was to evaluate the quality of meat from five new slowgrowing chicken combinations. The results could be used for selection of suitable genotypes that would respond to consumers' demands for healthy and dietetic food.

\section{MATERIAL AND METHODS}

The experiment was carried out in the experimental base of Poultry and Rabbit Selection, Population Genetics and Technologies unit at the Agricultural Institute - Stara Zagora. Five combinations of slow-growing chickens obtained by crossing of five strains of chickens from the Bulgarian National Gene Pool were used. Strains used in breeding schedules:

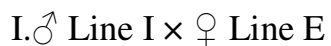

$$
\begin{aligned}
& \text { II. } \delta \text { Line } \mathrm{M} \times \propto \text { Line } \mathrm{E} \\
& \text { III. } \delta \text { Line } \mathrm{I} \times q \text { Line } \mathrm{F} \\
& \text { IV. } \widehat{O} \text { Line } \mathrm{M} \times \text { q Line } \mathrm{F} \\
& \text { V. } \widehat{\partial} \text { Line } \mathrm{I} \times \text { Line } \mathrm{Ss}
\end{aligned}
$$

used as maternal forms combined purpose Line $\mathrm{E}$ (Barred Plymouth Rock), Line Ss (Light Sussex), Line F, and paternal forms - the meat-type Line M (Cornish) and Line I.

Five groups of chickens were formed $(\mathrm{I} \times \mathrm{E}, \mathrm{M}$ $\times \mathrm{E}, \mathrm{I} \times \mathrm{F}, \mathrm{M} \times \mathrm{F}, \mathrm{I} \times \mathrm{Ss}$ ), each comprising 150 unsexed day-old marked and vaccinated chicks. 
Chickens were reared under uniform conditions indoor, in groups, on deep permanent wooden shavings litter (indoor - floor system) following the technology used in the selection base of the Agricultural Institute - Stara Zagora. Birds had permanent access to compound feed produced in the fodder plant of the institute, according to birds' age and category. Feeding schedule comprised offering starter ( 1 - 14 days of age), grower (15 - 28 days of age), and finisher ( $29-84$ days of age). The composition and nutritional value of compound feeds are listed in Table 1 (AOAC, 1996).

Table 1

Contents of nutrients in feed

\begin{tabular}{lccc}
\hline \hline & $\begin{array}{c}\text { Starter } \\
1-14 \text { days }\end{array}$ & $\begin{array}{c}\text { Grower } \\
\text { 15-28 days }\end{array}$ & $\begin{array}{c}\text { Finisher } \\
\text { 29-84 days }\end{array}$ \\
\hline Crude protein, \% & 21.16 & 19.37 & 18.77 \\
Crude fat, \% & 8.18 & 5.92 & 5.90 \\
Metabol. energy, kcal/kg & 1927.77 & 2148.15 & 2194.26 \\
Crude fiber, \% & 4.45 & 4.11 & 4.12 \\
Ca, \% & 0.97 & 0.90 & 0.78 \\
Digestible phosphorus, \% & 0.806 & 0.45 & 0.69 \\
Methionine, \% & 0.46 & 0.44 & 0.38 \\
Lysine, \% & 1.19 & 1.11 & 0.98 \\
\hline \hline
\end{tabular}

By the end of the experiment at 84 days, slaughter analysis was performed with 3 female and 3 male broiler chickens per group with live weight corresponding to the group average of each genotype and sex. After 12 hour fasting, the birds were stunned and slaughtered according to the stipulations of Ordinance 22/14.12.2005 of the Ministry of Agriculture. The analysis of meat quality traits was conducted at the Meat and Meat Products Unit, Faculty of Agriculture, Trakia University - Stara Zagora.

\section{Proximate analysis}

Chemical composition of meat was determined on samples from breast (m. Pectoralis superficialis, $m$. Pectoralis profundus) and thigh muscles $(m$. Femorotibialis) without skin. Meat samples were collected on the $24^{\text {th }}$ hour after slaughter. All analyses were run in duplicate using methods adapted and described by Zahariev and Pinkas (1979).
Water content (\%) was determined by drying of minced samples $(5 \mathrm{~g})$ at $105^{\circ} \mathrm{C}$ to constant weight.

Protein content (\%) was assayed by the method of Kjeldahl. The total nitrogen content was calculated as protein percentage using a coefficient of 6.25 .

Fat content (\%) was determined by the method of Soxhlet through ether extraction.

Ash content (\%) was obtained by burning minced meat samples $(5 \mathrm{~g})$ in a muffle furnace, initially for about $30 \mathrm{~min}$ at $200^{\circ} \mathrm{C}$, then the temperature was elevated to $550^{\circ} \mathrm{C}$ for 24 hours, and finally to $750^{\circ} \mathrm{C}$ for $30 \mathrm{~min}$, followed by determination of the ultimate weight of the sample. All measurements were made in duplicate

\section{Physicochemical analysis}

Meat $\mathrm{pH}$ and water holding capacity of whole meat (WHC) were determined by the $45^{\text {th }}$ minute $\left(\mathrm{pH}_{45}\right)$ post mortem by means of "Testo 205 " $\mathrm{pH}$ meter on samples from $m$. Pectoralis superficialis, $m$. Pectoralis profundus and m. Femorotibialis. The analysis was made using the classical method of Grau and Hamm (1953), described by Zahariev and Pinkas (1979) modified by Petrov (1982).

The muscle tissue sample was placed onto a filter paper (red strip 388) between two glass plates, and pressure of $5 \mathrm{~kg}$ for $5 \mathrm{~min}$ was applied. The percentage of released free water was calculated using the formula:

$$
\text { WHC, } \% *=\frac{a-b}{a} \cdot 100,
$$

where:

WHC - water holding capacity of muscles, \%;

$a$ - mass of muscle sample prior to pressing, g;

$b$ - mass of muscle sample after pressing, g;

* - higher percentage of water loss is associated with lower WHC values.

Cooking loss was determined with breast ( $m$. Pectoralis) and thigh (m. Femorotibialis) meat in an air convection oven. For this purpose, samples with approximate size $2 / 2 \mathrm{~cm}$ were weighed with precision of $0.01 \mathrm{~g}$ and cooked in an oven previously heated to $150^{\circ} \mathrm{C}$ for $20 \mathrm{~min}$. The method principle was based on attaining a temperature of $75-80^{\circ} \mathrm{C}$ in the core of the sample (Petracci and Baeza, 2011). Cooking loss was calculated by the equation:

$$
\text { Cooking loss, } \%=\frac{a-b}{a} .100 \text {, }
$$


where:

$a$-weight of meat sample before cooking, g;

$b$ - weight of meat sample after cooking, $g$.

\section{Statistical analysis}

The results were submitted to statistical analysis (ANOVA/MANOVA and LSD post hoc test) to determine the effect of the genotype and the sex using Statistica 8 software (StatSoft, 2009). Percentage data were arcsine transformed prior to the statistical analysis.

\section{RESULTS AND DISCUSSION}

\section{Effect of genotype}

The dietetic properties of meat are primarily dependent on its composition and ratios between the different groups of nutrients. Table 2 demonstrated a significant effect of genotype on meat proximate analysis parameters.

The content of protein is of particular importance. Its values were the highest in breast muscle of slow-growing chickens $\mathrm{I} \times \mathrm{F}-24.30 \%$. It should be noted that $\mathrm{M} \times \mathrm{F}$ crosses showed the lowest protein meat content: $23.62 \%(\mathrm{p}<0.05)$. In the other genetic groups, meat protein content was almost the same. The highest thigh protein content was measured in $\mathrm{I} \times \mathrm{F}, \mathrm{I} \times \mathrm{E}$ and $\mathrm{M} \times \mathrm{E}$ hybrids (20.31 - 20.46 $\%)$ without statistically significant differences. There were considerably differences vs. genotypes $\mathrm{I} \times \mathrm{Ss}$ and $\mathrm{M} \times \mathrm{F}$, which exhibited the lowest meat protein values: 19.9 and $20 \%$ respecttively $(\mathrm{p}<$ 0.05).

Poultry meat fat is a relevant part of meat dietetic properties. In the breast muscle, fat content showed a trend opposite to that of meat protein content, e.g. it was the lowest in $\mathrm{I} \times \mathrm{F}$ chickens $(1.29 \%)$ followed by $\mathrm{M} \times \mathrm{F}-1.47 \%$ vs. $1.77 \%$ in $\mathrm{I} \times \mathrm{Ss}$.

Table 2

Chemical composition of breast and thigh meat of different broiler genotypes (\%)

\begin{tabular}{|c|c|c|c|c|c|c|c|c|c|}
\hline \multirow{2}{*}{ Genotype } & \multirow{2}{*}{ Sex } & \multicolumn{4}{|c|}{ Breast meat } & \multicolumn{4}{|c|}{ Thigh meat } \\
\hline & & Moistue & Protein & Fat & Ash & Moisture & Protein & Fat & Ash \\
\hline \multirow{3}{*}{$\mathrm{I} \times \mathrm{E}$} & 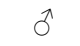 & 73.55 & 23.99 & 1.44 & 1.01 & 73.79 & 20.36 & 4.87 & 0.98 \\
\hline & q & 73.36 & 23.78 & 1.88 & 0.98 & 73.25 & 20.52 & 5.26 & 0.98 \\
\hline & $\hat{o}+q$ & $73.46 \mathrm{~b}$ & $23.89 \mathrm{~b}$ & $1.66 \mathrm{ab}$ & $0.99 \mathrm{~b}$ & $73.52 \mathrm{~d}$ & $20.44 \mathrm{a}$ & $5.07 \mathrm{a}$ & $0.98 \mathrm{ac}$ \\
\hline \multirow{3}{*}{$\mathrm{M} \times \mathrm{E}$} & $\sigma^{\lambda}$ & 73.60 & 24.01 & 1.38 & 1.02 & 73.91 & 20.66 & 4.46 & 0.97 \\
\hline & q & 73.44 & 23.67 & 1.81 & 1.04 & 74.02 & 20.25 & 4.75 & 1.04 \\
\hline & $\hat{o}+9$ & $73.52 \mathrm{~b}$ & $23.84 \mathrm{~b}$ & $1.59 \mathrm{ab}$ & $1.03 \mathrm{a}$ & $73.96 \mathrm{~b}$ & $20.46 \mathrm{a}$ & $4.60 \mathrm{~b}$ & $1.01 \mathrm{a}$ \\
\hline \multirow{3}{*}{$\mathrm{I} \times \mathrm{F}$} & 0 & 73.57 & 24.71 & 0.75 & 1.01 & 74.16 & 20.09 & 4.77 & 0.98 \\
\hline & q & 73.26 & 23.88 & 1.82 & 1.05 & 73.30 & 20.53 & 5.22 & 0.95 \\
\hline & $\hat{o}+p$ & $73.42 \mathrm{bc}$ & $24.30 \mathrm{a}$ & $1.29 \mathrm{c}$ & $1.03 \mathrm{a}$ & $73.73 \mathrm{~cd}$ & $20.31 \mathrm{a}$ & $5.00 \mathrm{a}$ & $0.96 \mathrm{ab}$ \\
\hline \multirow{3}{*}{$\mathrm{M} \times \mathrm{F}$} & $\hat{0}$ & 73.60 & 24.08 & 1.33 & 1.00 & 74.02 & 20.21 & 4.78 & 0.99 \\
\hline & $q$ & 74.18 & 23.16 & 1.62 & 1.04 & 73.82 & 19.78 & 5.50 & 0.90 \\
\hline & $\hat{o}+9$ & 73.89 a & $23.62 \mathrm{c}$ & $1.47 \mathrm{cb}$ & $1.02 \mathrm{ab}$ & $73.92 \mathrm{bc}$ & $20.00 \mathrm{~b}$ & $5.14 \mathrm{a}$ & $0.95 \mathrm{bc}$ \\
\hline \multirow{3}{*}{$\mathrm{I} \times \mathrm{Ss}$} & $\hat{0}$ & 73.29 & 23.92 & 1.79 & 1.00 & 74.09 & 20.04 & 4.95 & 0.92 \\
\hline & q & 73.33 & 23.86 & 1.74 & 1.07 & 74.31 & 19.76 & 4.96 & 0.93 \\
\hline & $\hat{o}+q$ & $73.31 \mathrm{c}$ & $23.89 \mathrm{~b}$ & $1.77 \mathrm{a}$ & $1.03 \mathrm{a}$ & $74.20 \mathrm{a}$ & $19.90 \mathrm{~b}$ & $4.96 \mathrm{a}$ & $0.93 \mathrm{~b}$ \\
\hline \multicolumn{2}{|l|}{$\begin{array}{l}\text { Sex } \\
\text { Male }\end{array}$} & 7352 & 244 & 134 & 101 & 7400 & 2026 & 479 & 096 \\
\hline \multicolumn{2}{|l|}{ Female } & 73.52 & 23.67 & 1.77 & 1.03 & 73.74 & 20.17 & 4.97 & 0.96 \\
\hline \multicolumn{2}{|l|}{$\begin{array}{l}\text { ANOVA } \\
\text { Genotype }\end{array}$} & 0.000 & 0.000 & 0.000 & 0.005 & 0.000 & 0.000 & 0.006 & 0.012 \\
\hline \multicolumn{2}{|l|}{ Sex } & 0.898 & 0.000 & 0.000 & 0.000 & 0.000 & 0.044 & 0.000 & 0.615 \\
\hline \multicolumn{2}{|l|}{$\mathrm{G} \times \mathrm{S}$} & 0.000 & 0.000 & 0.000 & 0.000 & 0.000 & 0.000 & 0.152 & 0.034 \\
\hline
\end{tabular}


Thigh fat percentage was the lowest only in $\mathrm{M}$ $\times \mathrm{E}$ chickens $-4.60 \%(\mathrm{p}<0.05)$. The differences among the other combinations were not significant with fat ranging within $4.96-5.14 \%$. According to Thornton (2016) breast protein and fat content in slow-growing broilers varied between $24.30-24.66$ $\%$ and $1.01-1.18 \%$, respectively. Culioli et al. (1990) assumed that the higher fat content of muscle tissue resulted in better flavour of meat of slowgrowing broilers. Guan et al (2013) found out a considerable effect of the genotype on protein and lipid content in $m$. Pectoralis major. In a similar experiment, Brunel et al. (2006) also confirmed that their amount was associated to poultry genotype. Unlike us, Fanatico et al. (2005) concluded that meat fat content was not influenced by genotype. Substantial differences in meat fat content between broilers with different growth rate were neither observed by Latter-Dubois (2000).

Water varying within $72-75 \%$ is the main constituent of poultry meat (Zahariev et al, 1991) that influences its juiciness, colour, consistency and appearance. The results from Table 2 showed that breast meat with the highest moisture content (respecttively the lowest dry matter content) was that of $\mathrm{M} \times \mathrm{F}$ crosses $(73.89 \%)$ while the lowest water content of breast meat was found out in $\mathrm{I} \times \mathrm{F}$ and $\mathrm{I}$ $\times$ Ss hybrids: 73.42 and $73.31 \%$ respectively $(\mathrm{p}<$ 0.05). Thigh moisture percentage was the highest for the I $\times$ Ss combination $(74.20 \%$ ) followed by $\mathrm{M}$ $\times \mathrm{F}$ hybrids $(73.92 \%)$ and the lowest values were detected in $\mathrm{I} \times \mathrm{E}$ chickens $-73.52 \%(\mathrm{p}<0.05)$.

Crude ash in poultry meat comprises all mineral components - mineral salts, macrominerals and trace elements. The ash content established in this study was $1.02-1.03 \%$, with statistically significantly lower values in the breast meat of $\mathrm{I} \times \mathrm{E}$ chickens $(p<0.05)$. Thigh ash did not differ substantially in $\mathrm{I} \times \mathrm{E}, \mathrm{M} \times \mathrm{E}$ and $\mathrm{I} \times \mathrm{F}$ crosses and ranged within $0.96-1.01 \%$. A slightly lower mineral content was found out in I $\times$ Ss thigh muscles. The results reported on the genotype effect on dry matter and ash content of poultry meat are contradictory. While Latter-Dubois (2000), Fanatico et al. (2005) reported no influence of genotype, the data of Holcman et al. (2003) provided evidence for a substantial effect of genotype on breast meat dry matter, which was in line with our data. In addition, Choo et al. (2014) detected a relationship between breast meat moisture and protein content and genotype, but a lack of association between genotype and meat lipid and mineral contents. In an experiment with slow-growing chickens obtained by two- and three-line crossing, Sarica et al. (2014) also presented significant differences in thigh dry matter and protein as well as in breast dry matter, protein and fat. In a comparative study on chemical indices of thigh muscles in three genotypes of fowl, Petkov (2013) found out differences in meat proximate analysis parameters except for moisture content.

The analysis of physicochemical parameters of breast and thigh meat showed a statistically significant association with genotype expect for WHC of breast muscle. Meat potential of hydrogen $(\mathrm{pH})$ is a key factor involved in conversion of muscle into meat. The analysis of $\mathrm{pH}_{45}$ thigh values (Table 3) during the first 45 minutes revealed statistically significant differences among studied genotypes with the highest values in slow-growing chickens $\mathrm{I} \times \mathrm{Ss}$ -6.11 and the lowest - for $\mathrm{M} \times \mathrm{E}$ crosses -5.79 (p $<0.05$ ). Breast muscles pH (Table 3) showed also differences among genetic groups. Breast muscle $\mathrm{pH}$ of $\mathrm{I} \times \mathrm{E}, \mathrm{M} \times \mathrm{F}$ and $\mathrm{I} \times \mathrm{Ss}$ genotypes did not differ considerably and ranged within $5.50-5.52$. A substantially lower value was observed for breast $\mathrm{pH}$ of I $\times$ F chickens: $5.40(\mathrm{p}<0.05)$. In general, breast muscle $\mathrm{pH}$ of studied hybrids declined rapidly and the commonest reason for this was the extensive glycolysis when the carcass temperature was still high (Takahashi et al., 2008). Low pH decreased water holding capacity and meat tenderness while increased cooking losses (Le Bihan-Duval et al., 2008; Damaziak et al., 2013). According to some researchers, $\mathrm{pH}$ values of $5.7-5.8$ several minutes after death could be considered as indicated PSE type of meat (Strzyżewski et al., 2008). Allen et al. (1997) affirmed that higher meat $\mathrm{pH}$ resulted in drier, thicker and darker appearance of meat. Such meat was more susceptible to rapid microbial; spoilage compared to paler meats with lower $\mathrm{pH}$ values.

The meat $\mathrm{pH}$ analysis allowed affirming that glycogen reserves in breast and thigh muscles and the rate of post mortem anaerobic glycolysis in studied broiler genotypes were different.

The comparison of results agreed with earlier conclusions of Mehaffey et al. (2006) about a significant influence of the genotype on meat $\mathrm{pH}$ measured on post mortem hours 2 and 4. On the contrary, Wang et al (2009) reported higher $\mathrm{pH}$ values of pectoralis muscles 45 min post mortem - 5.75. In another study, Batkowska et al. (2014) indicated breast and thigh muscle $\mathrm{pH}$ on the $60^{\text {th }}$ post mortem minute of 5.70 and 5.95 in two slow-growing hybrids $(\mathrm{C} \times \mathrm{Sx}$ and $\mathrm{C} \times \mathrm{GP}$, respectively). 
Table 3

Physicochemical properties of breast and thigh meat of different broiler genotypes

\begin{tabular}{|c|c|c|c|c|c|c|c|}
\hline \multirow[b]{2}{*}{ Genotype } & \multirow[b]{2}{*}{ Sex } & \multicolumn{3}{|c|}{ Breast meat } & \multicolumn{3}{|c|}{ Thigh meat } \\
\hline & & $\mathrm{pH}_{45}$ & $\begin{array}{l}\text { WHC } \\
(\%)\end{array}$ & $\begin{array}{c}\text { Cooking loss } \\
(\%)\end{array}$ & $\mathrm{pH}_{45}$ & $\begin{array}{c}\text { WHC } \\
(\%)\end{array}$ & $\begin{array}{l}\text { Cooking loss } \\
(\%)\end{array}$ \\
\hline \multirow{3}{*}{$\mathrm{I} \times \mathrm{E}$} & $\hat{\sigma}$ & 5.56 & 25.04 & 28.56 & 6.11 & 24.11 & 23.92 \\
\hline & 우 & 5.43 & 31.29 & 35.62 & 5.80 & 24.35 & 36.02 \\
\hline & $\hat{\sigma}+$ + & $5.50 \mathrm{a}$ & 28.16 & $32.09 \mathrm{a}$ & $5.95 \mathrm{~b}$ & $24.23 \mathrm{~b}$ & $29.97 \mathrm{a}$ \\
\hline \multirow{3}{*}{$M \times E$} & $\hat{0}$ & 5.52 & 30.13 & 29.38 & 5.82 & 28.17 & 22.36 \\
\hline & q & 5.40 & 30.35 & 32.90 & 5.76 & 28.61 & 36.57 \\
\hline & $\hat{\delta}+q$ & $5.46 \mathrm{~b}$ & 30.24 & $31.14 \mathrm{a}$ & $5.79 \mathrm{~d}$ & $28.39 \mathrm{a}$ & $29.47 \mathrm{a}$ \\
\hline \multirow{3}{*}{$\mathrm{I} \times \mathrm{F}$} & $\sigma^{\lambda}$ & 5.42 & 27.91 & 25.74 & 5.84 & 29.25 & 21.58 \\
\hline & q & 5.38 & 29.35 & 29.65 & 5.90 & 24.08 & 33.20 \\
\hline & $\partial+q$ & $5.40 \mathrm{c}$ & 28.63 & $27.69 \mathrm{~b}$ & $5.87 \mathrm{c}$ & $26.66 \mathrm{a}$ & $27.39 \mathrm{bc}$ \\
\hline \multirow{3}{*}{$\mathrm{M} \times \mathrm{F}$} & $\hat{0}$ & 5.57 & 28.12 & 25.20 & 6.09 & 22.50 & 19.32 \\
\hline & q & 5.47 & 28.19 & 30.82 & 5.85 & 22.62 & 34.07 \\
\hline & $\hat{j}+q$ & $5.52 \mathrm{a}$ & 28.15 & $28.01 \mathrm{~b}$ & $5.97 \mathrm{~b}$ & $22.56 \mathrm{~b}$ & $26.69 \mathrm{c}$ \\
\hline \multirow{3}{*}{$\mathrm{I} \times \mathrm{Ss}$} & $\hat{\sigma}$ & 5.52 & 27.61 & 28.33 & 6.13 & 25.11 & 21.92 \\
\hline & q & 5.49 & 30.90 & 36.45 & 6.09 & 22.33 & 34.04 \\
\hline & $\hat{j}+q$ & $5.51 \mathrm{a}$ & 29.26 & $32.39 \mathrm{a}$ & $6.11 \mathrm{a}$ & $23.72 \mathrm{~b}$ & $27.98 \mathrm{~b}$ \\
\hline \multicolumn{8}{|l|}{ Sex } \\
\hline Male & & 5.52 & 27.76 & 27.44 & 6.00 & 25.83 & 21.82 \\
\hline Female & & 5.44 & 30.01 & 33.09 & 5.88 & 24.40 & 34.78 \\
\hline \multicolumn{8}{|l|}{ ANOVA } \\
\hline Genotype & & 0.000 & 0.141 & 0.000 & 0.000 & 0.000 & 0.000 \\
\hline Sex & & 0.000 & 0.000 & 0.000 & 0.000 & 0.012 & 0.000 \\
\hline $\mathrm{G} \times \mathrm{S}$ & & 0.000 & 0.007 & 0.025 & 0.000 & 0.006 & 0.038 \\
\hline
\end{tabular}

$\mathrm{a}-\mathrm{d}-$ different letters within a column indicate statistically significant differences at $\mathrm{p}<0.05$

The quality of meat as a raw material for storage and processing depends on its hydrophilic properties - water holding capacity (WHC) and cooking losses. The good WHC guarantees excellent technological meat properties while low WHC results in less juicy and harder meat (Wang et al. 2009). The $\mathrm{pH}$ values of meat during the first post mortem hours had the greatest influence on WHC. Regardless of the differences in $\mathrm{pH}$ values, WHC of breast meat did not differ considerably among genotypes and ranged from 28.15 to $30.24 \%$. These results were comparable to those reported by Musa et al. (2006), Michalczuk et al. (2014), Sarica et al. (2014), Puchała et al. (2015) who stated that the genotype-related differences in breast WHC were insignificant. The percentage of released free water from thigh meat was higher in $\mathrm{I} \times \mathrm{F}$ and $\mathrm{M} \times \mathrm{E}$ chickens - from 26.66 to $28.39 \%$, which was associated with decreased content of valuable watersoluble proteins and vitamins. The obtained cooking loss values of breast meat from slow-growing hybrids I $\times \mathrm{F}$ and $\mathrm{M} \times \mathrm{F}$ were lower compared to all others: in the range $27.69-28.01 \%$ vs. $31.14-32.39 \%$ (p $<0.05)$. Similar results were observed with regard to thigh, and the lowest cooking loss percentage was found out again in hybrid combinations $\mathrm{M} \times \mathrm{F}$ and $\mathrm{I} \times \mathrm{F}(26.69$ and $27.39 \%$ respectively; $p<0.05)$. Statistically significantly higher values were obtained in chickens from $\mathrm{I} \times \mathrm{E}$ and $\mathrm{M} \times \mathrm{E}$ combinations: 29.97 and $29.47 \%$ respectively $(\mathrm{p}<0.05)$. The studies of Lonergan et al. (2003) and Fanatico et al. (2005) on meat quality also confirmed that cooking loss depended greatly on the genotype, while Abdullah et al. (2010) did not report any relevant differences for 4 studied broiler genotypes.

\section{Effect of sex and genotype $\times$ sex interaction}

In this study, no substantial variation was found out with respect to breast moisture and thigh mineral content which were almost the same in birds of both genders: $73.52 \%$ and $0.96 \%$ respectively, 
but there was a statistically significant effect of the genotype $\times$ sex interaction with the highest values of breast moisture in female $\mathrm{M} \times \mathrm{F}$ chickens (74.18 $\%)$ and thigh meat of $\mathrm{I} \times$ Ss chickens $(74.31 \%)$. Thigh moisture content was low, but statistically significantly higher in male birds (74\%) vs. $73.74 \%$ in females (Table 2).

Sex had a significant effect on lipid content of both muscles with higher values in females -1.77 $\%$ vs. $1.34 \%$ in breast meat and $4.97 \%$ vs. $4.79 \%$, in thigh meat $(\mathrm{p}<0.001)$. The combined effect of genotype and sex resulted in the lowest fat content in the breast meat of male $\mathrm{I} \times \mathrm{F}$ hybrids $(0.75 \%)$.

The protein content of breast and thigh was higher in male birds $-24.14 \%$ and $20.26 \%$, respectively. Having in mind the relevant genotype $\times$ sex interaction, the highest protein meat content was found out in the breast muscles of male $\mathrm{I} \times \mathrm{F}(24.71$ $\%)$ and in the thigh meat of $\mathrm{M} \times \mathrm{E}$ chickens (20.66 $\%)$. The studied breast meat samples in chickens from both sexes differed also with respect to ash content which was superior in females -1.03 vs. $1.01 \%$, with the highest values in female $\mathrm{I} \times \mathrm{Ss}$ chickens $(1.07 \%)$ resulting from the interaction of both factors.

Although no differences were detected in thigh mineral content depending on the gender, there was a significant effect of genotype $\times$ sex interaction with the highest values in male $\mathrm{M} \times \mathrm{E}$ chickens $(1.04 \%, \mathrm{p}<0.05)$. Our results confirmed the data of Bogosavljević-Bošković et al. (2010) for substantially higher content of fat and lower protein in breast and thigh meat of female chickens as compared to male. Lopez et al. (2011) investigated the moisture and protein percentage of breast and thigh meat and did not found a significant variation depending on the gender unlike us. According to Sarica et al. (2014), no genotype $\times$ sex interaction on nutritional value of meat did exist in line with our results. Comparably, Souza et al. (2011) observed an interaction of the factors with regard to breast fat content.

The results from physicochemical analysis of both muscle confirmed a significant effect of the gender on studied parameters $(\mathrm{p}<0.001)$, as well as significant genotype $\times$ sex interaction. In female chickens, breast and thigh $\mathrm{pH}$ were lower $-5.44 \%$ and $5.88 \%$, while cooking loss percentages were higher $33.09 \%$ vs $27.44 \%$ for breast meat and $34.78 \%$ vs. $21.82 \%$ for thigh meat. The genotype $\times$ sex interaction resulted in the lowest breast $\mathrm{pH}_{45}$ of the $\mathrm{I} \times \mathrm{F}$ combination -5.38 , and the lowest thigh $\mathrm{pH}$ in female $\mathrm{M} \times \mathrm{E}$.
The investigation of genotype $\times$ sex interaction on cooking losses of both muscles demonstrated the lowest values in male $\mathrm{M} \times \mathrm{F}: 25.20 \%$ for breast meat resulting from higher $\mathrm{pH}$ and $19.32 \%$ for thigh meat. The lowest amount of lost water was established for breast meat of male I $\times$ E chickens -25.04 $\%$, whereas the best WHC was exhibited by thigh meat of female $\mathrm{I} \times \mathrm{Ss}-22.33 \%$. Our results for meat $\mathrm{Ph}$ were comparable with those reported by Salakova et al. (2009), Lopez et al. (2011), e.g. higher values in male birds and at a certain extent with the data of Sarica et al. (2014), indicating differences only in breast but not for thigh meat $\mathrm{pH}$. In contrast to our data, other authors have not found out a gender effect on breast $\mathrm{pH}$ (Musa et al. 2006) and cooking losses (Souza et al. 2011), and experiments with quails (Genchev et al., 2010) and broiler chickens (Abdullah et al. 2010) reported higher cooking losses in male birds as compared to female.

\section{CONCLUSION}

The results from the experiment demonstrated differences in chemical and physicochemical parameters of breast muscles (except for WHC) and thigh muscle in the five studied slow-growing chicken genotypes. The meat of the I $\times$ F combination was outlined with high nutritional value (the highest meat protein and mineral contents; the lowest water and fat content) and with considerably lower cooking losses vs. the other studied combinations. The sex had a relevant influence on meat proximate analysis results as could be seed from the higher fat content and lower protein content of both muscles in females $(\mathrm{p}<0.001)$. The moisture and mineral contents in the thigh were not affected. Breast meat of male birds had better technological properties - high WHC as well as low cooking loss percentage for both studied muscle types.

The differences in meat quality were associated with the effects of genotype, sex and their interaction.

\section{REFERENCES}

[1] Abdullah, A. Y., Al-Beitawi, N. A., Rjoup, M. M. S., Qudsieh, R. I., \& Ishmais, M. A. A.: Growth performance, carcass and meat quality characteristics of different commercial crosses of broiler strains of chicken. The J. Poul. Sci., 47 (1), 12-21 (2010).

[2] Allen, C. D., S. M. Russel and D. I. Fletcher: The relationship of broiler breast meat colour and $\mathrm{pH}$ to shelf-life and odour development. Poultry Sci., 76, 1042-1046 (1997). 
[3] Association of Official Analytical Chemists (AOAC). Official Methods of Analyses (16th ed.). VA, 1996.

[4] Batkowska, J. A., Brodacki, S. Knaga and M. Florek.: Slaughter traits and skin colour of newly crossed chicken broilers dedicated for extensive rearing system as a criterion of product identification and meat quality, Acta Agriculturae Scandinavica, Section A - Animal Science, Volume 64 (2014).

[5] Bogosavljević-Bošković, S., Mitrović, S., Djoković, R., Dosković, V., V. Djermanović.: Chemical composition of chicken meat produced in extensive indoor and free range rearing systems. African Journal of Biotechnology, 9 (53): 9069-9075 (2010).

[6] Brunel, V., Jehl, N., Drouet, L. and Portheau M. C.: Viande de volailles : Sa valeur nutritionnelle présente bien des atouts.Viandes et Produits Carnés 25 (1), 5 p. (2006).

[7] Castellini, C., Dal Bosco A., Mugnai C., Pedrazzoli A.: Comparison of two chicken genotypes organically reared: oxidative stability and other qualitative traits of the meat. Italian Journal of Animal Science 5, 355-363 (2006).

[8] Castellini, C., Berri C., Le Bihan-Duval, E., Martino, G.: Qualitative attributes and consumer perception of organic and free-range poultry meat. World Poultry Sci. J., 64: 500-512 (2008).

[9] Choo, Yun-Kyung, Sung-Taek Oh, Kyung-Woo Lee, Chang-Won Kang, Hyun-Wook Kim, Cheon-Jei Kim, Eun-Jib Kim, Hee-Sung Kim and Byoung-Ki An.: The Growth Performance, Carcass Characteristics, and Meat Quality of Egg-Type Male Growing Chicken and WhiteMini Broiler in Comparison with Commercial Broiler (Ross 308). Korean J. Food Sci. An. Vol. 34, 5, pp. 622629 (2014).

[10] Culioli, J., C. Touraille, P. Bordes and J. P. Girard.: Characteristiques des carcasses et de la viande du poulet 'label fermier'. Arch. Geflügelk. 53, 237-245 (1990).

[11] Damaziak, K., Pietrzak, D., Michalczuk, M., Mroczek, J. and Niemiec J.: Effect of genotype and sex on selected quality attributes of turkey meat. Arch. Geflügelk., 77 (3). S. 206-214 (2013).

[12] Debut M., Berri C., Baéza E., Sellier N., Arnould C., Guémené D., Jehl N., Boutten B., Jego Y., Beaumont C., Le Bihan-Duval E.: Variation of chicken technological meat quality in relation to genotype and preslaughter stress conditions. Poultry Science 82, 1829-1838 (2003).

[13] Díaz, O., Rodríguez, L., Torres, A., Cobos, A.: A fatty acid composition of the meat from Mos breed and commercial strain capons slaughtered at different ages. Grasas Aceites, 63. 296-302 (2012).

[14] Eleroğlu, H., Yıldırım, A., Işıkl, N. D., Şekeroğlu, A., Duman. M.: Comparison of meat quality and fatty acid profile in slow-growing chicken genotypes fed diets supplemented with Origanum vulgare or Melissa officenalis leaves under the organic system. Italian Journal of Animal Science, 12 (3): 395-403 (2013).

[15] Fanatico, A. C., Cavitt, L. C., Pillai, P. B., Emmert, J. L., Owens, C. M.: Evaluation of slowergrowing broiler genotypes grown with and without outdoor access: meat quality. Poultry Science 84: 1785-1790 (2005).

[16] Fengli, An, Xiaohong Kang, Lu Zhang, Leilei, Jinbao Wang, Baoping Shao Wang, J.: Comparison of muscle properties and meat quality between Jing Ning chicken and
Ling Nan Huang Yu meat chicken. Journal of Food, Agriculture and Environment, 11 (1), 54-58 (2013).

[17] Genchev, A., Ribarski, S., Zhelyazkov, G.: Physicochemical and technological properties of Japanese quail meat. Trakia Journal of Sciences, 8 (4), 86-94 (2010).

[18] Guan, R. F., Lyu, F., Chen, X. Q., Ma, J. Q, Jiang, H., Xiao, C. G.: Meat quality traits of four Chinese indigenous chicken breeds and one commercial broiler stock. Journal of Zhejiang University - SCIENCE B (Biomedicine \& Biotechnology), 14 (10), 896-902 (2013), DOI: 10.1631 jzus.B1300163

[19] Holcman, A., Vadnjal R., Žlender B. and Stibilj V.: Chemical composition of chicken meat from free range and extensive indoor rearing. Archiv für Geflugelkunde 67 (3), 120-124 (2003).

[20] Jaturasitha, S., Kayan A., Michael W.: Carcass and meat characteristics of male chickens between Thai indigenous compared with improved layer breeds and their crossbred. Archives of Animal Breeding (Arch. Tierz.), Dummerstorf 51 (3), 283-294 (2008b).

[21] Jaturasitha, S., Srikanchai T., Kreuzer, M., Wicke, M.: Differences in carcass and meat characteristics between chicken indigenous to Northern Thailand (Black - Boned and Thai Native) and imported extensive breeds (Bresse and Rhode Island Red). Poultry Sci., 87: 160-169 (2008).

[22] Latter-Dubois, J.,: Poulets fermiers: leurs qualités nutritionnelles et organoleptiques et la perception du consommateur. M. Sc. thesis. Faculte' des Sciences de l'Agriculture et de l'Alimentation, University Laval, Quebec, Canada, 2000, $86 \mathrm{p}$.

[23] Le Bihan-Duval, E., Debut M., Berri C. M., Sellier N., Santé-Lhoutellier V., Jégo Y., Beaumont C.: Chicken meat quality: genetic variability and relationship with growth and muscle characteristics. BMC Genet. 9,53 (2008).

[24] Lonergan, S. M., Deeb, N., Fedler, C. A., Lamont, S. J.: Breast meat quality and composition in unique chicken populations. Poult Sci., 82 (12), 1990-4 (2003).

[25] López, K. P., Schilling, M. W., Corzo, A.: Broiler genetic strain and sex effects on meat characteristics. Poultry Sci., 90, 1105-1111 (2011).

[26] Mehaffey, J. M., Pradhan, S. P., Meullenet, J. F., Emmert, J. L. McKee, S. R., Owens, C. M.: Meat quality evaluation of minimally aged broiler breast fillets from five commercial strains. Poult. Sci. 85:902-908 (2006).

[27] Michalczuk, M., Łukasiewicz, M., Zdanowska-Sąsiadek, Ż., Niemiec, J.: Comparison of selected quality attributes of chicken meat as affected by rearing systems. Pol. J. Food Nutr. Sci., 64, 121-126 (2014).

[28] Mikulski， D., J. Celej, J. Jankowski, T. Majewska, Mikulska. M.: Growth performance, carcass traits and meat quality of slower-growing and fast-growing chickens raised with and without outdoor access. Asian-Aust. J. Anim. Sci. 24,1407-1416 (2011).

[29] Musa, H. H., Chen, G. H., Cheng, J. H., Shuiep, E. S., Bao, W. B.: Breed and sex effect on meat quality of chicken. International Journal of Poultry Science 5 (6), 566-568 (2016).

[30] Ordinance 22 of Agriculture and Food of 14.12.2005. Ordinance to minimize animal suffering during slaughter or killing. 
[31] Petkov, E.,: Comparative study of the main chemical and biochemical parameters of thigh muscles of three genotypes of birds. XXXV International conference business meeting with exhibition, „Poultry Farming 2013”. Poultry Farming, 6, 20-23.(Bg) (2013).

[32] Petkov, E.: Comparative study of three types of combinations of chicks with different growth rates. Dissertation for awarding the NSA "Doctor", Kostinbrod, 2013.

[33] Petracci, M., Baeza, E.: Harmonization of methodologies for the assessment of poultry meat quality features. Worlds Poultry Sci J. 67 (1), 137-151 (2011).

[34] Petrov, Y.: Species and breed related particularities in skeletal muscle microstructure during the ontogenesis of productive animals. DSc thesis, Stara Zagora, 1982.

[35] Połtowicz, K., Doktor, J. : Effect of slaughter age on performance and meat quality of slow-growing broiler chickens. Ann. Anim. Sci., 12, 621-631 (2012).

[36] Puchała, M., Krawczyk, J., Sokołowicz, Z., Utnik-Banaś K.: Effect of breed and production system on physicochemical characteristics of meat from multi-purpose hens. Ann. Anim. Sci., 15. 247-261 (2015).

[37] Riedel, J., Michalczuk, M., Zdanowska-Sąsiadek Ż.: Assessment of slaughter value of three broiler chicken genotypes. Anim. Sci., 52, 179-185 (2013).

[38] Saláková, A., Straková, E., Válková, V., Buchtová, H., Steinhauserová, I.: Quality indicators of chicken broiler raw and cooked meat depending on their sex. Acta Vet. Brno. 78: 497-504 (2009).

[39] Sarica, M., Yamak, U. M., Boz, M. A.: Comparing growth and carcass traits of slow growing chicken parents with pure egg type parents and commercial broilers. Hayvansal Üretim, 55, 1-8 (2014).
[40] Sokołowicz, Z., Krawczyk, J., Świątkiewicz, S.. Quality of poultry meat from native chicken breeds - a review. Ann. Anim. Sci., 16 (2), 347-368 (2016).

[41] Souza, X. R., Faria, P. B., Bressan, M. C.: Proximate composition and meat quality of broilers reared under different production systems. Brazilian Journal of Poultry Science, 13 (1), 15-20 (2011).

[42] Strzyżewski, T., Bilska, A., Krzysztofiak, K.: Zależność pomiędzy wartością $\mathrm{pH}$ mięsa a jego barwą. Nauka Przyroda Technologie, 2 (2), 1-9 (2008).

[43] Takahashi, S.E., Mendes, A.A., Komiyama, C.M. et al.: Efeito da temperatura ambiente sobre a qualidade da carne de frangos. PUBVET, 2 (22) Art\# 242 (2008).

[44] Thornton, G.: The expanding market for slow-growing broilers. WATT Poultry USA, 22-27 (2016).

[45] Tougan, P. U., Dahouda, M., Salifou, C. F. A., Ahounou, G. S., Kossou, D. N. F., Amenou, C., Kogbeto, M. T., Kpodekon, M. T., Mensah, G. A., Lognay, G., Thewis, A., Youssao, I. A. K.: Nutritional quality of meat from local poultry population of Gallus gallus species of Benin. $J$. Anim. Plant. Sci., 19, 2908-2922 (2013).

[46] Umaya, S. R.: The uniqueness of immunocompetence and meat quality of native chickens: a specialized review. World J. Pharm. Pharmaceut. Sci., 3, 2576-2588 (2014).

[47] Wang, K. H, Shi S. R, Dou T. C, Sun H. J.: Effect of a free-range raising system on growth performance, carcass yield, and meat quality of slow-growing chicken. Poult Sci. 88, 2219-2223 (2009).

[48] Zahariev, Z. Pinkas, A.: Methods for slaughter analysis and quality control of the meat. NAIU, Sofia, 1979.

[49] Zanetti, E., De Marchi, M., Dalvit, C., Molette, C., Remignon, H. Cassandro, M.: Carcass characteristics and qualitative meat traits of three Italian local chicken breeds, British Poultry Science, 51, 5, 629-634 (2010). 
